\title{
Amyloidogenic, neuroinflammatory and memory dysfunction effects of HIV-1 gp120
}

\author{
Young-Jung Lee ${ }^{3} \cdot$ In Jun $\mathrm{Yeo}^{1} \cdot$ Dong Young $\mathrm{Choi}^{2}$ • \\ Jaesuk Yun ${ }^{1} \cdot$ Dong Ju Son ${ }^{1} \cdot$ Sang-Bae Han ${ }^{1}$. \\ Jin Tae Hong ${ }^{1}$ (D)
}

Received: 1 April 2021 / Accepted: 30 June 2021 / Published online: 23 July 2021

(C) The Author(s) 2021

\begin{abstract}
Human immunodeficiency virus 1 (HIV-1) infection can cause several HIV-associated neurocognitive disorders a variety of neurological impairments characterized by the loss of cortical and subcortical neurons and decreased cognitive and motor function. HIV-1 gp120, the major envelope glycoprotein on viral particles, acts as a binding protein for viral entry and is known to be an agent of neuronal cell death. To determine the mechanism of HIV-1 gp120-induced memory dysfunction, we performed mouse intracerebroventricular (i.c.v.) infusion with HIV-1 gp120 protein (300 ng per mouse) and investigated memory impairment and amyloidogenesis. Infusion of the HIV-1 gp120 protein induced memory dysfunction, which was evaluated using passive avoidance and water maze tests. Infusion of HIV-1 gp120 induced neuroinflammation, such as the release of iNOS and COX-2 and the activation of astrocytes and microglia and increased the mRNA and protein levels of IL-6, ICAM-1, M-CSF, TIM, and IL-2. In particular, we found that the infusion of HIV-1 gp120 induced the accumulation of amyloid plaques and signs of elevated
\end{abstract}

Young-Jung Lee and In Jun Yeo have contributed equally to this work

Jin Tae Hong

jinthong@chungbuk.ac.kr

1 College of Pharmacy and Medical Research Center, Chungbuk National University, Osongsaengmyeong 1-ro, Osong-eup, Heungdeok-gu, Cheongju, Chungbuk 28160, Republic of Korea

2 College of Pharmacy, Yeungnam University, 280 Daehak Road, Gyeonsan, Gyeongbuk 38541, Republic of Korea

3 Department of Equine Resources Science, School of Equine and Horticultural, Cheju Halla University, 38 Halladaehak-ro, Jeju-si, Jeju Special Self-Governing Province 63092, Republic of Korea amyloidogenesis, such as increased expression of amyloid precursor protein and BACE1 and increased $\beta$-secretase activity. Therefore, these studies suggest that HIV-1 gp120 may induce memory impairment through $A \beta$ accumulation and neuroinflammation.

Keywords HIV-1 - gp120 - Amyloid beta . Neuroinflammation

\section{Introduction}

Alzheimer's disease (AD) is the most common cause of dementia, accounting for $50-75 \%$ of all cases (Ferri et al. 2009; Lee et al. 2010) and the most common neurological complication. $\mathrm{AD}$ is defined by progressive synaptic impairment, excessive formation and accumulation of amyloidbeta $(\mathrm{A} \beta$ ), and neuroinflammation (Blennow et al. 2006; Lee et al. 2010). Although the underlying mechanism of $\mathrm{AD}$ development remains unclear, experimental data have demonstrated that neuroinflammation-mediated $\mathrm{A} \beta$ accumulation in the brain may initiate and/or contribute to the process of AD development (Lee et al. 2010; Choi et al. 2012; Shadfar et al. 2015). It is well-known that viral proteins can activate macrophages, astrocytes and microglial cells that lead to the production of inflammatory molecules, further damaging neurons (Kaul et al. 2001).

Much of the associated research indicates that there are some common factors and pathways modulated in $\mathrm{HIV}^{+}$ and $\mathrm{AD}$ patients, thus suggesting some similarities exist between these two diseases. Among numerous factors, neuroinflammation is considered a common and crucial factor in the development and progression of two conditions. It has been reported that HIV-1 gp120, a fragment proteolytically cleaved from the Env protein, can activate 
neuroinflammatory pathways in the central nervous system (CNS), resulting in neuronal injury and dysfunction (Ortega and Ances 2014; Ru and Tang 2017). In addition, levels of cytokines, such as CCL3, IL-8, CCL2, IFN- $\gamma$, CXCL10, and IL-6, were found to be higher in HIV-1-infected individuals than in uninfected individuals (Kamat et al. 2012).

Furthermore, the envelope protein gp120 has been demonstrated to trigger the release of TNF- $\alpha$ and IL- $1 \beta$ which elicit neuronal apoptosis in numerous ex vivo and in vivo studies (Garden et al. 2002; Shah et al. 2011). Gp120injected primary hippocampal cells have demonstrated the promotion of $A \beta_{1-42}$ secretion (Aksenov et al. 2010). The brain of $\mathrm{HIV}^{+}$patients showed increased expression of BACE1 (commonly observed with AD) (Stern et al. 2018). However, there are no definite data demonstrating a causal relationship between HIV-1 infection and neuronal damage or the onset of AD. Therefore, in the present study, we examined whether injection of the HIV-1 gp120 protein affects the development of $\mathrm{AD}$ and whether this effect is related to neuroinflammation-mediated $\mathrm{A} \beta$-accumulation in the brain.

\section{Materials and methods}

\section{HIV-1 gp120 infused mouse model}

A total of 20 5-week-old male ICR mice weighing 25-30 g (Samtako, Gyeonggi-do, Korea) were maintained in accordance with the Institutional Animal Care and Use Committee (IACUC) of Laboratory Animal Research Center at Chungbuk National University, Korea (CBNU404-12-01). All mice were housed in a room that was automatically maintained at $21-25{ }^{\circ} \mathrm{C}$ and relative humidity (45-65\%) with a controlled $12 \mathrm{~h}$ light-dark cycle. To study HIV-1 gp120-induced abnormalities, the mice were randomly allocated to two groups. Group 1 (control group; $n=10$ ) was injected saline vehicles, and group 2 (HIV-1 gp120 group; $n=10$ ) was injected HIV-1 gp120 protein. In each group, all administrations of only saline or saline containing HIV-1 gp120 protein were performed through intracerebroventricular (icv) injection. All mouse were anesthetized with ketamine/xylazine cocktail at $100 \mathrm{mg} /$ $\mathrm{kg}$ ketamine and $10 \mathrm{mg} / \mathrm{kg}$ xylazine by injecting intraperitoneally (IP). The depth of anesthesia was monitored by the loss toe pinch reflex. The method of icv injection was summarized as below: $1 \mu \mathrm{l}$ saline $(0.9 \% \mathrm{NaCl})$ containing $300 \mathrm{ng}$ gp120 was injected stereotaxically into the third ventricle to be $0.25 \mathrm{~mm}$ posterior to the bregma of mice $2.4 \mathrm{~mm}$ in depth (anteroposterior, $-0.25 \mathrm{~mm}$; mediolateral, $0 \mathrm{~mm}$; dorsal ventral, $-2.4 \mathrm{~mm}$ relative to the bregma). The next behavioral experiments were performed after 21 days following the injection. Recombinant HIV-1 IIIB Glycoprotein gp120 was purchased from ImmunoDX, LLC (Woburn, MA). Experimental scheme was shown in Fig. 1.

\section{Water maze test}

The water maze test is also a widely accepted method for memory test, and we performed this test as described by Morris (1984). Maze testing was performed by the SMARTCS (Panlab, Barcelona, Spain) program and equipment. A circular plastic pool (height: $35 \mathrm{~cm}$, diameter: $100 \mathrm{~cm}$ ) was filled with non-toxic black ink water kept at $22-25{ }^{\circ} \mathrm{C}$. An escape platform (height: $14.5 \mathrm{~cm}$, diameter: $4.5 \mathrm{~cm}$ ) was submerged $0.5-1 \mathrm{~cm}$ below the surface of the water in position. The test performed three times a day for 5 days during the acquisition phase (Days 1-5), with three randomized starting points. The position of the escape platform was kept constant. Each trial lasted for $60 \mathrm{~s}$ or ended as soon as the mice reached the submerged platform. Swimming pattern of each mouse was monitored and recorded by a camera mounted above the center of the pool, and the escape latency, escape distance and swimming speed were assessed by the SMART-LD program (Panlab, Barcelona, Spain). A quiet environment, constant water temperature was
Fig. 1 Experimental scheme. $300 \mathrm{ng}$ gp120 was injected into the third ventricle of mice brain. After 21 days following injection, the memorial abnormalities were performed through behavioral tests of water maze test, probe test and step-through test, sequentially as shown in Fig. 1

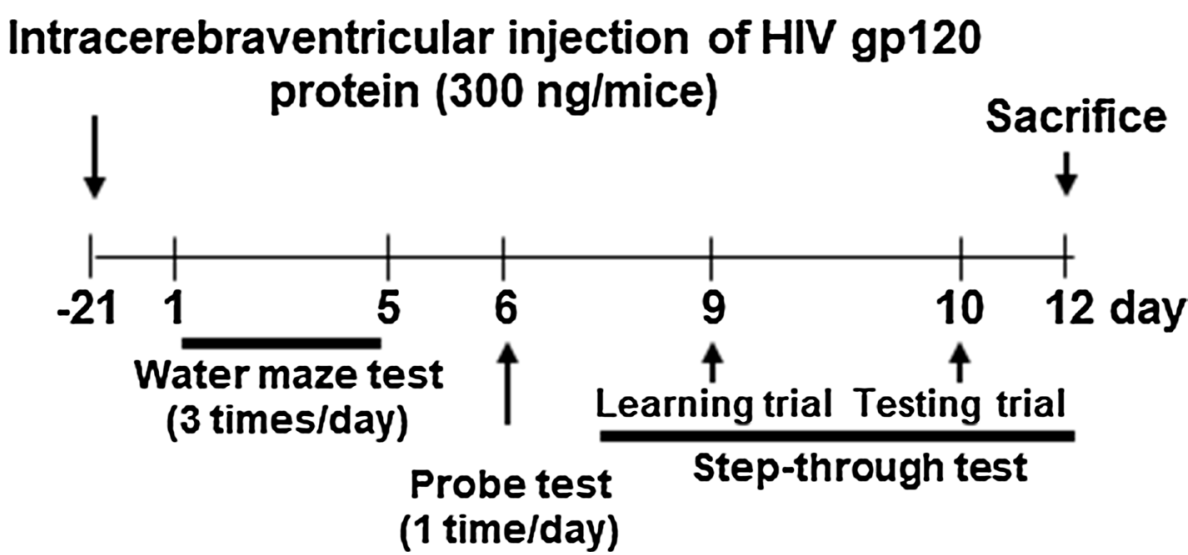


maintained throughout the experimental period. The water maze test was used in 10 mice per group.

\section{Probe test}

A probe trial in order to assess memory consolidation was performed $24 \mathrm{~h}$ after the water maze tests. In this trial, the platform was removed from the tank, and the mice were allowed to swim freely. For these tests, percentage time in the target quadrant and target site crossings within $60 \mathrm{~s}$ was recorded. The time spent in the target quadrant is taken to indicate the degree of memory consolidation that has taken place after learning. Swimming pattern of each mouse was monitored by a camera above the center of the pool connected to a SMART-LD program described above. The probe test was used in 10 mice per group.

\section{Passive avoidance performance test}

The passive avoidance test is also widely accepted as a simple and rapid test method for measuring memory capacity. The passive avoidance response was determined using a "step-through" apparatus (Med Associates, Inc., Georgia, VT, USA) that is consisted of an illuminated and a dark compartment (each $20.3 \times 15.9 \times 21.3 \mathrm{~cm}$ ) adjoining each other through a small gate with a grid floor, $3.175 \mathrm{~mm}$ stainless steel rod set $8 \mathrm{~mm}$ apart. One day after water maze test, training trial was performed. The mice were placed in the illuminated compartment facing away from the dark compartment. When the mice moved completely into the dark compartment, it received an electric shock $(1 \mathrm{~mA}, 3 \mathrm{~s}$ duration). Then the mice were returned to their home case. At 1 day later, the mice were placed in the illuminated compartment and the latency period to enter the dark compartment defined as "retention" was measured. The time when the mice entered in the dark compartment were recorded and described as step-through latency. The retention trials were set at a limit of $180 \mathrm{~s}$ of cut-off time. The passive avoidance performance test was used in 10 mice per group.

\section{Brain collection and preservation}

After behavioral test (step through test), animals were perfused with PBS under inhaled ether anesthetization. The brains were immediately collected in the same manner and separated into cortical and hippocampal regions. All the brain regions were immediately stored at $-80{ }^{\circ} \mathrm{C}$ and used to for measure biological assay.

\section{Immunohistochemistry}

Mice were anesthetized with ether. While under general anesthesia, the mice received intracardiac perfusion with
$20 \mathrm{ml}$ of saline. Brains were fixed in formalin and paraffin-enclosed for examination. $6 \mu \mathrm{m}$-thick tissue sections were used with immunohistochemistry. Paraffin-embedded sections were deparaffinized and rehydrated, washed in distilled water, and then subjected to heat-mediated antigen retrieval treatment. Endogenous peroxidase activity was quenched by incubation in $2 \%$ hydrogen peroxide in methanol for $30 \mathrm{~min}$ and then cleared in PBS for $5 \mathrm{~min}$. The sections were blocked for 30 min with $3 \%$ normal horse serum diluted in PBS. Immunohistochemical staining was performed using the avidin-biotin-peroxidase method. The sections were incubated overnight at $4{ }^{\circ} \mathrm{C}$ with appropriate antibodies; $\mathrm{A} \beta_{1-42}$ (1:2000 dilution, Covance, Berlely, CA, USA), GFAP (1:5000, Abcam, Inc, Cambridge, MA, USA), Iba1 (1:5000, Wako, Osaka, Japan), iNOS (1:100, Abcam, Inc, Cambridge, MA, USA), COX-2 (1:100, Cayman Chemical, Ann Arbor, MI, USA) and BACE1 (1:500, Sigma St. Louis, MO, USA). After washing in PBS, the sections were incubated in biotinylated secondary antibodies (1:2000 dilution, Vector Laboratories, Burlingame, CA, USA) for $1 \mathrm{~h}$ at room temperature. The sections were subsequently washed and incubated with avidin-conjugated peroxidase complex (ABC kit, 1:200 dilution. Vector Laboratories) for $30 \mathrm{~min}$ followed by PBS washing. The peroxidase reaction was performed in PBS using 3,3'-diaminobenzidine tetrahydrochloride (DAB, $0.02 \%$ ) as the chromogen. It was then counterstained by a hematoxylin. Finally, sections were dehydrated in ethanol, cleared in xylene, and mounted with Permount (Fisher Scientific, Hampton, NH), and evaluated on a light microscopy (Olympus, Tokyo, Japan). To determine the expression of iNOS, COX-2, BACE1, GFAP, and Iba1, the stained cells by each antibody were counted. The six sections with three different animal brains were analyzed, and cells at three randomly selected areas $(100 \times 100 \mu \mathrm{m})$ in each section were assessed. The immunoreactive cells by anti-iNOS, COX-2, BACE1, GFAP and Iba1 antibody were counted, and expressed as percentage of stained cells. The quantity of reactive cells was expressed as the average number of reactive cells per high power field (visible reactive cells/HPF).

To simultaneously determine level of $\mathrm{A} \beta$, we performed immunofluorescence assay in paraffin section of brain. The sections were then incubated to mouse monoclonal antibody for $A \beta_{1-42}$ (1:2000, Clone No. 4G8, Covance, Berkeley, CA, USA) overnight at $4{ }^{\circ} \mathrm{C}$. After washes with ice-cold PBS, followed by treatment with an anti-mouse secondary antibody labeled with Alexa Flour 488 (1:100 dilution, Molecular Probes, Inc., Eugene, OR) for $2 \mathrm{~h}$ at room temperature, immunofluorescence images were acquired using a confocal laser scanning microscope (TCS SP2, Leica Microsystems AG, Wetzlar, Germany). Areas of amyloid deposition in mice brain were identified by staining of $0.2 \%$ thioflavine $\mathrm{S}$ 
(Sigma St. Louis, MO, USA) and microscopic evaluation. For detection of anti-A $\beta$ antibody- and thioflavin S-double positive staining, digital images were acquired using a confocal laser scanning microscope (TCS SP2, Leica Microsystems AG, Werzlar, Germany).

\section{Western blotting analysis}

Tissues were homogenized with lysis buffer [ $50 \mathrm{mM}$ Tris $\mathrm{pH}$ $8.0,150 \mathrm{mM}$ sodium chloride $(\mathrm{NaCl}), 0.02 \%$ sodium azide, $0.2 \%$ sodium dodecyl sulfate (SDS), $1 \mathrm{mM}$ phenylmethanesulphonyl fluoride, $10 \mu \mathrm{l} / \mathrm{ml}$ aprotinin, $1 \%$ IGAPEL CA-630, $10 \mathrm{mM}$ sodium fluoride, $0.5 \mathrm{mM}$ ethylenediaminetetraacetic acid (EDTA), $0.1 \mathrm{mM}$ ethylene glycol tetraacetic acid and $0.5 \%$ sodium deoxycholate] and centrifuged at $15,000 \times g$ for $15 \mathrm{~min}$. Equal amount of proteins $(40 \mu \mathrm{g})$ were separated on a SDS/10 and $15 \%$ polyacrylamide gel and then transferred to a polyvinylidene difluoride membrane (GE Water and Process Technologies). Blots were blocked for $1 \mathrm{~h}$ at room temperature with $5 \%(\mathrm{w} / \mathrm{v})$ non-fat dried milk in Trisbuffered saline [10 mM Tris (pH 8.0) and $150 \mathrm{mM} \mathrm{NaCl}$ ] solution containing $0.05 \%$ Tween 20 . The membrane was then incubated for $3 \mathrm{~h}$ at room temperature with specific antibodies: anti-C99, anti-APP (1:500, ABR-Affinity Bioreagents, Golden, CO, USA), anti-A $\beta$ (1:500, 4G8, Covance, Berlely, CA, USA), anti-BACE1 (1:500, Sigma St. Louis, MO, USA), anti- $\beta$-actin (1:2000, Santa Cruz Biotechnology, Inc., Santa Cruz, CA, USA), anti-iNOS (1:100, Abcam, Inc, Cambridge, MA, USA), anti-COX-2 (1:100, Cayman Chemical, Ann Arbor, MI, USA), anti-GFAP (1:1000; Abcam Inc., Cambridge, MA, USA) and anti-Iba1 (1:1000; Abcam Inc., Cambridge, MA, USA) were used. The blots were then incubated with the corresponding peroxidase-conjugated anti-goat/rabbit/mouse antibodies (1:2000; Santa Cruz Biotechnology, Inc., Santa Cruz, CA, USA). Immunoreactive proteins were detected using ECL Western blotting detection system. The densitometric scanning of relative density of the protein bands was performed using MyImage (SLB, Seoul, South Korea) and quantified by Lab Works 4.0 (UVP Inc., Upland, CA, USA).

\section{Measurement of $A \beta_{1-42}$}

Lysates of brain tissue were obtained through protein extraction buffer containing protease inhibitor. $A \beta_{1-42}$ levels were determined using specific ELISA Kit (Immuno-Biological Laboratories Co., Ltd., Takasaki-Shi, Gunma, Japan). In brief, $100 \mu \mathrm{l}$ of sample was added into the pre-coated plate and was incubated for overnight at $4{ }^{\circ} \mathrm{C}$. After washing each well of the precoated plate with washing buffer, $100 \mu \mathrm{l}$ of labeled antibody solution was added and the mixture was incubated for $1 \mathrm{~h}$ at $4{ }^{\circ} \mathrm{C}$ in the dark. After washing, chromogen was added, and the mixture was incubated for $30 \mathrm{~min}$ at room temperature in the dark. Finally, the resulting color was assayed at $450 \mathrm{~nm}$ using a microplate absorbance reader (SunriseTM, TECAN, Switzerland) after adding stop solution.

\section{Measurement of $\beta$-secretase activity}

$\beta$-secretase activity in the brains was determined using commercially available $\beta$-secretase fluorescence resonance energy transfer (BACE1 FRET) assay kit (PANVERA, Madison, USA) according to the manufacturer's protocols and as described elsewhere. This formation of fluorescence was read using a Fluostar galaxy fluorometer (excitation at $355 \mathrm{~nm}$ and emission at $510 \mathrm{~nm}$ ) with Felix software (BMG Labtechnologies). $\beta$-secretase activity was expressed as $\mathrm{nmol} /(\mathrm{mg}$ protein-min).

\section{Reverse transcription PCR analysis}

Total RNA was extracted using the RNAqueous kit (Applied Biosystems, Foster city, CA). The cDNA was synthesized using High-Capacity RNA-to-cDNA kit (Applied Biosystems, Foster city, CA) according to the manufacturer's protocol. Briefly, $1 \mu \mathrm{g}$ of total RNA was used for cDNA preparation. The primers for IL-16, soluble intercellular adhesion molecule-1 (ICAM-1), macrophage colony-stimulating factor (M-SCF), T cell immunoglobulin and mucin domain-1 (TIM-1), IL-2 and glyceraldehyde-3-phosphate dehydrogenase (GAPDH) as an internal PCR control were as follows: 5'-AAA TGG ACA CTG CCA ATG GTG CTC-3' (sense) and 5'-AAA GGA GCT GAT TCT CTG CCG GAT-3' (antisense) for IL-16, 5'-AAA CGG GAG ATG AAT GGT ACC TAC-3' (sense) and 5'-TGC ACG TCC CTG GTG ATA CTC-3' (antisense) for ICAM-1, 5'-AGT GGT CTG TAA GCT CCA TC-3' (sense) and 5'-GAG CTT CTT GCA ATG GGT TG-3' (antisense) for M-CSF, 5'-CTA TGT TGG CAT CTG CAT CG-3' (sense) and 5'-AAG GCA ACC ACG CTT AGA GA-3' (antisense) for TIM-1 and 5'-TCC CTC AAG ATT GTC AGC AA-3' (sense) and 5'-AGA TCC ACA ACG GAT ACA TT-3' (antisense) for GAPDH. All PCRs were run in a 7500 Real-Time PCR System (Applied Biosystems, Foster city, CA, USA). The PCR cycles consisted of denaturation at $94{ }^{\circ} \mathrm{C}$ for $30 \mathrm{~s}$; annealing at $55^{\circ} \mathrm{C}$ for $30 \mathrm{~s}$ (GAPDH), $50{ }^{\circ} \mathrm{C}$ for $30 \mathrm{~s}$ (M-CSF and ICAM-1) or $60{ }^{\circ} \mathrm{C}$ for $30 \mathrm{~s}$ (IL-16 and TIM-1); and extension at $72{ }^{\circ} \mathrm{C}$ for $90 \mathrm{~s}$ for 30 cycles. The PCR product was separated by electrophoresis on a $1.5 \%$ agarose gel, stained with ethidium bromide and then detected under UV light. The densitometric scanning of relative density of the PCR bands was quantified by Lab Works 4.0 (UVP Inc., Upland, CA, USA). 


\section{Cytokine arrays}

Mouse Cytokine Array Panels were used according to the manufacturer instructions (R\&D Systems Inc., Minneapolis, MN, USA). Briefly, brain lysates were mixed with a cocktail of biotinylated detection antibodies prior to incubation at $4{ }^{\circ} \mathrm{C}$ with the array membranes. Following washing, streptavidin-horseradish peroxidase was applied for 30 min at ambient temperature. Immunoreactivity was then visualized using enhanced chemiluminescence reagent (GE Healthcare). Densitometric analysis was then performed using MyImage (SLB, Seoul, Korea) and quantified by Labworks 4.0 software (UVP Inc., Upland, CA, USA).

\section{Statistical analysis}

The data were statistically analyzed using the GraphPad Prism software (version 4.03; GraphPad software, Inc., San Diego, CA, USA). Data are presented as mean \pm SD. The group differences in all data were assessed by Student's $t$ test, one-way analysis of variance (ANOVA) followed by Bonferroni's post hoc test. A value of $p<0.05$ was considered statistically significant. \# Significantly different between the saline-injected group and HIV-1 gp120-injected group $(\mathrm{p}<0.05)$.

\section{Results}

\section{HIV-1 gp120 induced learning and memory impairment through icv injection in mice}

To investigate HIV-1 gp120-induced memory impairment effects in HIV-1 gp120-injected mice, we injected HIV-1 gp120 into the third ventricle of mouse brains and compared the learning and memory abilities to these mice to salineinjected mice using water maze, probe, and step-through tests. The mice were trained with three trials per day over 5 days; we then analyzed their ability to locate and escape onto the platform, and their spatial learning scores were recorded. Significant differences between HIV-1 gp120injected and control mice due to the memory impairment effect were seen on day two, and the impairment effect persisted for 5 days in the water maze test. The mice exhibited shorter escape latencies after training; however, the escape latency of the HIV-1 gp120-injected mice did not reduce as much as that of the saline-injected mice. HIV-1 gp120 in mice brains significantly impaired the memory ability of mice. Statistical analysis of data from days three to five showed the significance of the memory impairment effect of HIV-1 gp120 injection. The escape latency among the HIV-1 gp120-injected group $(35.4 \pm 5.6 \mathrm{~s})$ on day five was greater than that of the saline-injected group
$(18.2 \pm 3.7 \mathrm{~s}, p<0.001$, Fig. $2 \mathrm{~A})$. The swimming distance in the HIV-1 gp120-injected group $(979.4 \pm 167.9 \mathrm{~cm})$ on day five was also longer than that of the saline-injected group $(298.7 \pm 67.5 \mathrm{~cm}, p<0.001)$ (Fig. 2B). However, there was no significant difference in average speed between the saline-injected group and the HIV-1 gp120-injected group (data not shown). After the water maze test, we performed a probe test to assess the maintenance of memory. During the probe test, the time spent in the target quadrant by the HIV-1 gp120-injected group $(27.6 \pm 4.4 \%)$ was significantly decreased compared to that of the saline-injected group $(44.7 \pm 6.4 \%, p=0.01$, Fig. 2 C). We also evaluated learning and memory capacities with a passive avoidance test using a step-through method. In the passive avoidance test learning trial, there was no significant difference between the two groups. However, in the test trial, the step-through latency of the saline-injected group $(145.2 \pm 51.8 \mathrm{~s})$ had significantly decreased to $21.4 \pm 15.8 \mathrm{~s}(p<0.001)$ compared to the HIV-1 gp120-injection group (Fig. 2D).

\section{HIV-1 gp120 induced A $\beta$ accumulation in mouse brain}

Many studies have reported histopathological findings such as neuroinflammation and $A \beta$ accumulation in the brain of AIDS patients. To determine whether $A \beta$ accumulation is accompanied by HIV-1 gp120-induced memory dysfunction, we investigated the amyloidogenic effects of HIV-1 gp120-injection. Immunohistochemical analysis using an $\mathrm{A} \beta_{1-42}$ specific antibody showed $\mathrm{A} \beta$ deposition in the cortex and hippocampus regions of HIV-1 gp120-injected mouse brains but not in saline-injected mouse brains (Fig. 3A). To define the A $\beta$ accumulation in the HIV-1 gp120-injected mouse brain, we performed Congo red staining and found congophilic $\mathrm{A} \beta$ plaques in the HIV-1 gp120-injected mouse brains (Fig. 3B). To confirm the presence of each $\mathrm{A} \beta$ plaque, we performed immunofluorescence double-staining using an $\mathrm{A} \beta_{1-42}$ specific antibody and thioflavin $\mathrm{S}$ and we observed a plaque double-stained with both $\mathrm{A} \beta_{1-42}$ antibody and thioflavin S (Fig. 3C). Then, we investigated the expression level of amyloidogenesis-related proteins using Western blotting and found elevated expression of full-length APP, C99, A $\beta$, and BACE1 in the HIV-1 gp120-injected mouse brain (Fig. 3D). Moreover, the expression of neuronal $\beta$-secretase (BACE1) and the number of BACE1-positive cells were significantly increased by the HIV-1 gp120-injection (Fig. 4A).

Next, ELISA was performed to quantitatively measure $\mathrm{A} \beta_{1-40}$ and $\mathrm{A} \beta_{1-42}$ levels in the mouse brains. Both $\mathrm{A} \beta_{1-40}$ and $A \beta_{1-42}$ levels in the HIV-1 gp120-injected mouse brains were significantly higher compared with the levels of saline-injected mouse brains. The $A \beta_{1-42}$ protein level was $21.44 \pm 0.98 \mathrm{pg} / \mathrm{mg}$ in the control group brains and $65.51 \pm 7.83 \mathrm{pg} / \mathrm{mg}$ in the HIV-1 gp120-injected mouse brains (Fig. 4B and C). To determine how amyloid 

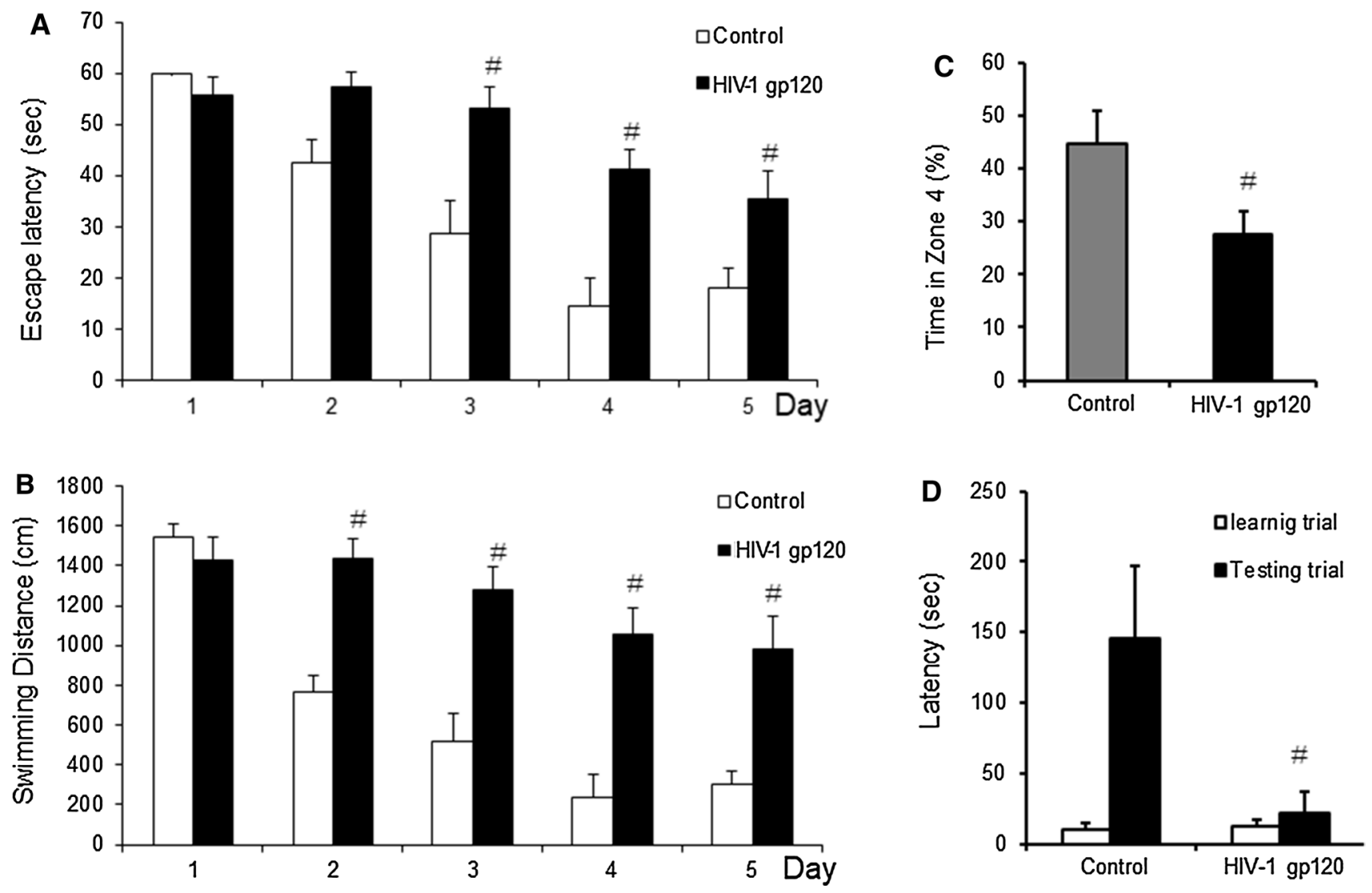

Fig. 2 Memorial impaired effects on HIV-1 gp120-induced abnormalities. To investigate memorial impaired effects in HIV-1 gp120-induced abnormalities, we performed water maze test $(\mathbf{A}, \mathbf{B})$, probe test $(\mathbf{C})$ and step-through type passive avoidance test (D). Memory function was determined by the escape latencies $(\mathbf{A}, \mathrm{s})$ and distance $(\mathbf{B}, \mathrm{cm})$ for 5 days, and time spent in target quadrant $(\mathbf{C}$, \%) in probe test after HIV-1 gp120-injection. Each value is mean \pm SD from 10 mice. \#, Significantly different from control group $(p<0.05)$. Control, saline-injected group. HIV-1 gp120, HIV-1 gp120-injected group

production was elevated by HIV-1 gp120-injection, we analyzed $\beta$-secretase activity in the brain and found it to be significantly increased with following the administration of the HIV-1 gp120-injection (Fig. 4D).

\section{HIV-1 gp120 induced the elevation of iNOS and COX-2 in mouse brain}

To investigate if the HIV-1 gp120-induced memory impairment and $A \beta$ accumulation were induced via neuroinflammation, the expression of iNOS was determined by immunohistochemical analysis. Upon HIV-1 gp120 treatment, the number of brown-colored (iNOS-labeled) cells was significantly higher in both the cerebral cortex and hippocampus of gp120-injected mice than in those of the control mice (Fig. 5A). Parallel with the expression level of iNOS detected by immunohistochemical analysis, Western blot analysis also showed that iNOS expression was significantly increased by gp120 injection into the mouse brain (Fig. 5C). Because NO can induce COX-2 expression, and COX-2 is an enzyme that regulates inflammation, we investigated the expression of COX-2 through immunohistochemical and Western blot analysis, which showed that HIV-1 gp120 injection also increased COX-2 expression (Fig. 5B and C).

\section{HIV-1 gp120 induces the activation of astrocytes and microglia in mouse brain}

Activation of neuroglia has also been implicated in amyloidogenesis and neuronal cell death during the development of AD. To investigate how HIV-1 gp120 injection induces the activation of astrocytes and microglia, we performed immunohistochemical analysis of GFAP- and Iba1-reactive cells in the brain GFAP- and Iba1-reactive cells were significantly more numerous in the cerebral cortex and hippocampus of gp 120-injected mice than those in control mice (Fig. 6A and B). Paralleled with the immunohistochemical results, Western blot analysis also showed that GFAP and 
A

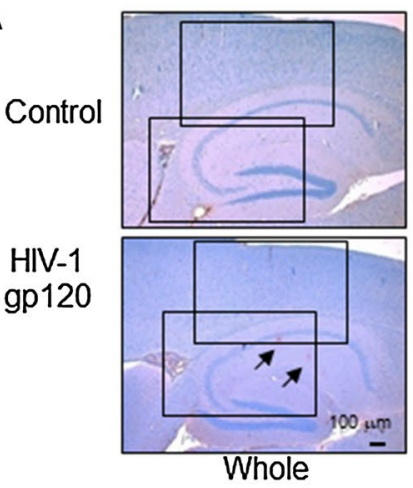

B

C

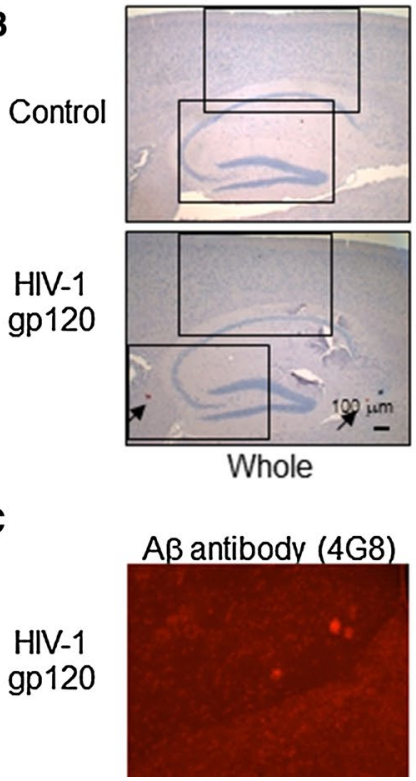

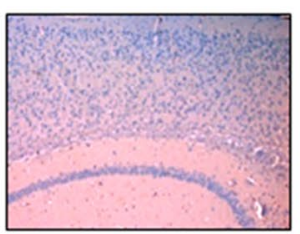

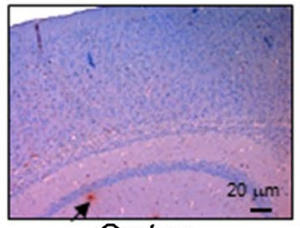

Cortex

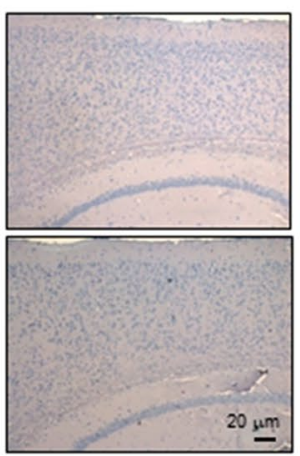

Cortex

Thioflavin S

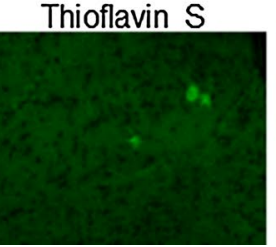

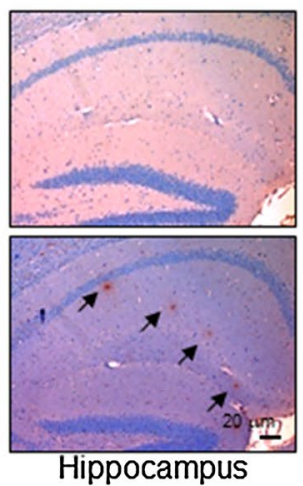

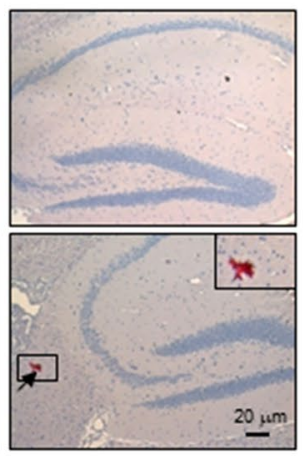

Hippocampus

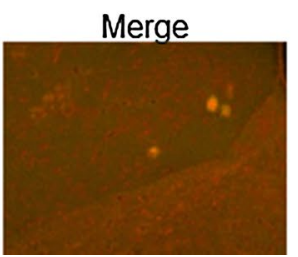

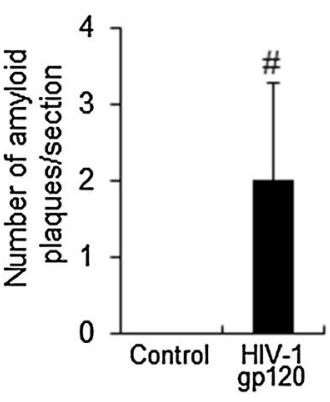

D

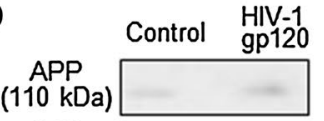

C99

(12 kDa)

BACE1

(60 kDa)

$(4 \mathrm{kDa})$

$\beta$-actin (42 kDa)

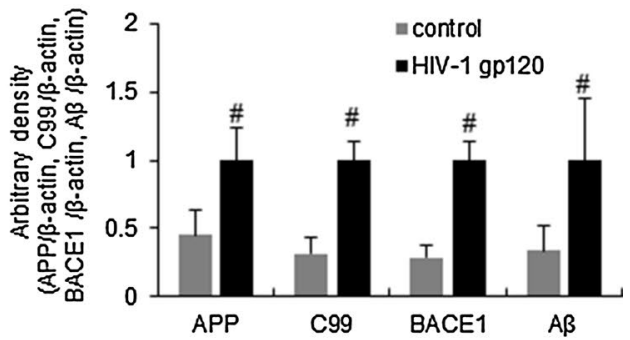

Fig. 3 A $\beta$ accumulation effect on HIV-1 gp120-injected mice brain. A Immunoreactive protein of anti-A $\beta_{1-42}$ antibody was investigated in the cortex and hippocampus. $6 \mu \mathrm{m}$-thick sections of brains from mice were incubated with anti-A $\beta_{1-42}$ antibody and counterstained with hematoxylin. Arrow indicates $A \beta_{1-42}$ accumulation which is clearly higher in the cerebral cortex and hippocampus of HIV-1 gp120-injected mice. Amyloid plaque detection via congo red staining $(\mathbf{B})$ and thioflavin $\mathbf{S}(\mathbf{C})$ was performed in the cortex and hippocampus. $6 \mu \mathrm{m}$-thick sections of brains were incubated with $0.2 \%$ congo red solution or thioflavin S solution for $20 \mathrm{~min}$ and counterstained with hematoxylin. Arrow indicates amyloid plaque which is clearly higher in the cerebral cortex and hippocampus of HIV-1 gp120-injected mice. C To define A $\beta_{1-42}$ accumulation in HIV-1 gp120-injected mice brain, co-immunostaining using anti-A $\beta_{1-42}$ antibody (red) and thioflavin S was performed. D The expression of APP, C99, A $\beta_{1-42}$, BACE1 in mice brain were detected by western blotting using specific antibodies. $\beta$-Actin protein was used as an internal control. Each blot is representative for three experiments. Control, saline-injected group. HIV-1 gp120, HIV-1 gp120-injected group

Iba1 levels were increased in the brains of gp120-injected mice (Fig. 6C).

\section{HIV-1 gp120 induced neuroinflammation}

To ascertain the cause of memory impairment induced by HIV-1 gp120 injection, we investigated several cytokine levels. Protein immuno-array results showed increased levels of IL-6, ICAM-1, M-CSF, TIM, and IL-2 (Fig. 7A). Moreover, RT-PCR analysis confirmed that HIV-1 gp120 injection increased the expression of these neuroinflammatory cytokines in the brain (Fig. 7B).

\section{Discussion}

The most important finding in this study was that administration of the HIV-1 gp120 protein induced memory impairment as well as amyloidogenesis and neuroinflammation in the mouse brain. It has been reported that HIV-1 proteins, including env, can directly influence the CNS and activate neuroinflammatory pathways, leading to neuronal injury and dysfunction. In addition, abnormal $\mathrm{A} \beta$, a pathological hallmark of $\mathrm{AD}$, was found to be deposited in individuals suffering from HIV-1 infection (Anderson et al. 2002; Zhang et al. 2015). 


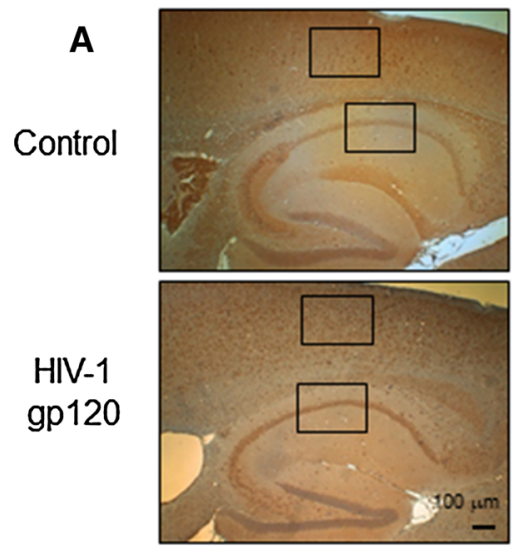

Whole

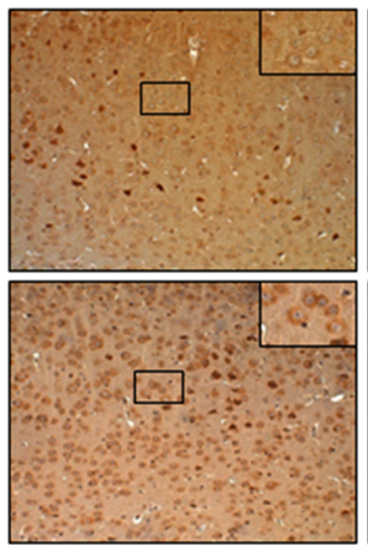

Cortex

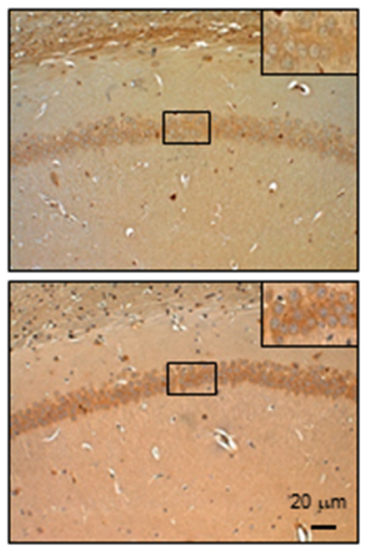

Hippocampus

(CA1)
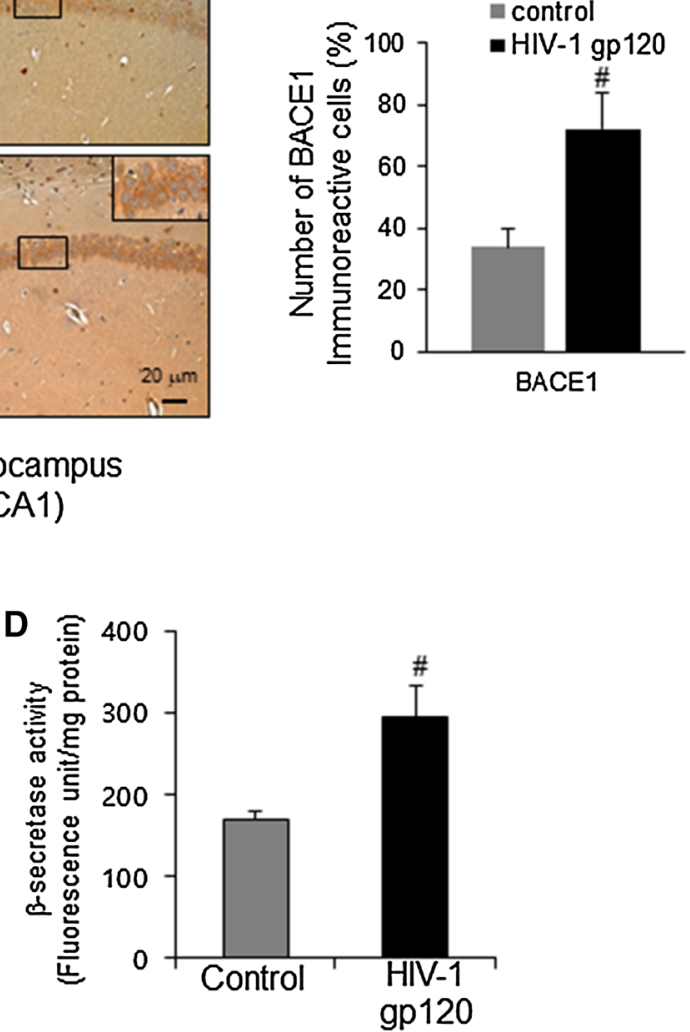

gp120
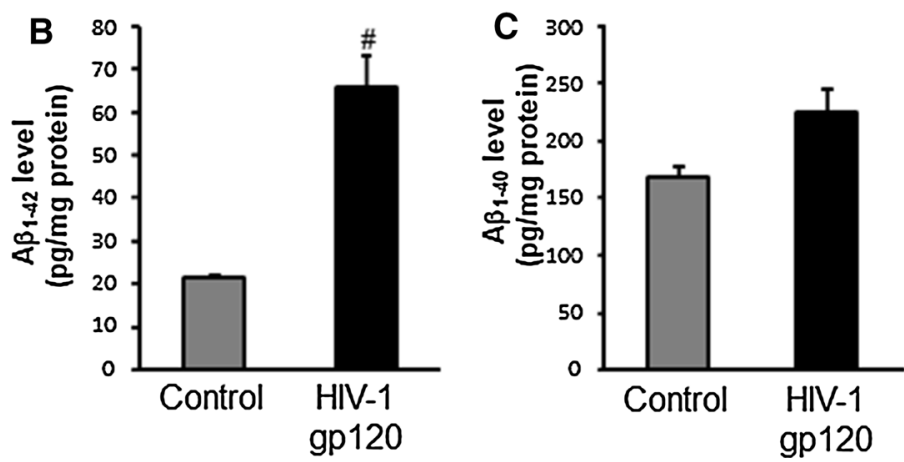

Fig. 4 Elevation effects of amyloidogenic proteins on HIV-1 gp120-injected mice brain. A Immunoreactive cells of anti-BACE1 antibody were investigated in the cortex and hippocampus. The present figure is representative for three different experiments with different animal brains. The levels of $\mathrm{A} \beta_{1-42}(\mathbf{B})$ and $\mathrm{A} \beta_{1-40}(\mathbf{C})$ was assessed by using a specific $\mathrm{A} \beta_{1-42}$ ELISA as described in Materials and methods. D The activity of $\beta$-secretase was investigated by using each assay kit as described in Materials and methods. Values measured from each group of mice were calibrated by amount of protein and expressed as mean $\pm \operatorname{SD}(n=5)$. \#, Significantly different from control group $(p<0.05)$. Control, saline-injected group. HIV-1 gp120, HIV-1 gp120-injected group

HIV-associated neurocognitive disorder (HAND) is a common primary neurological disorder associated with HIV infection. It is known that HAND patients often develop cognitive impairment, motor dysfunction and speech problems. Clinical severity of HAND ranges from asymptomatic neurocognitive impairment and mild neurocognitive disorder to HIV-associated dementia (HAD) (Ru and Tang 2017). Our study showed that injection of HIV-1 gp120 protein in mouse brain induced learning and memory impairment through water maze, probe and step-through tests. The impairment on the learning and memory capability is suggested to be caused by neuropathological change in HIV-1 gp120 injection.

Viral proteins take part in the inflammatory processes of neuronal cells and the activation of glial cells (GonzálezScarano and Martín-García 2005; Peng et al. 2011; F Hauser et al. 2012). Microglial cells play a fundamental role in the pathogenesis of neurodegenerative diseases such as AD.
HIV-1 infection causes glial cells to release several factors, including inflammatory factors that aggravate astrocytes and neurons. The activation of astrocytes reportedly leads to neuronal death and exhibits a correlation with brain damage associated with HIV-1 infection through sustained neuroinflammation (Mollace et al. 2001; Anderson et al. 2002; Minghetti et al. 2004). Positron emission tomography results for AIDS patients also demonstrated microglial activation (Zhang et al. 2012; Garvey et al. 2014). In addition, enhanced glial expression was observed among people with HIV-associated neurodegenerative disease. Therefore, excessive glial activation and neuroinflammation can contribute to cognitive impairment (Coughlin et al. 2014). Furthermore, one of two cleavages of HIV-1 Env protein, the gp120 protein has been demonstrated to release TNF- $\alpha$ and IL-1 $\beta$, which elicited neuronal apoptosis in numerous ex vivo and in vivo studies (Garden et al. 2002; Bachis et al. 2009). Similar to this effect, other cytokines such as IL-2, 


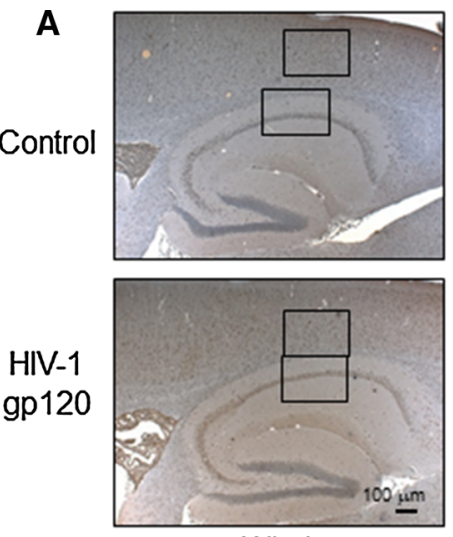

Whole
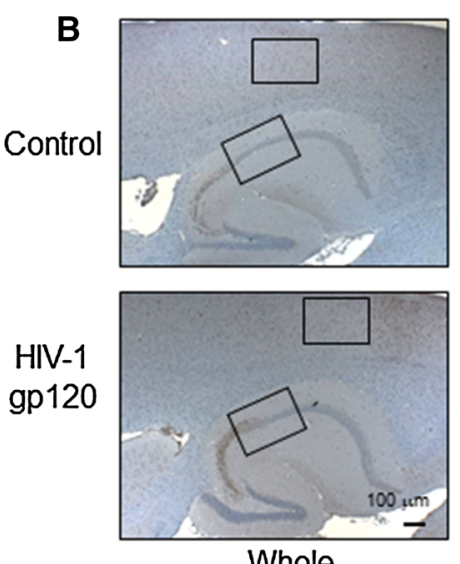

Whole
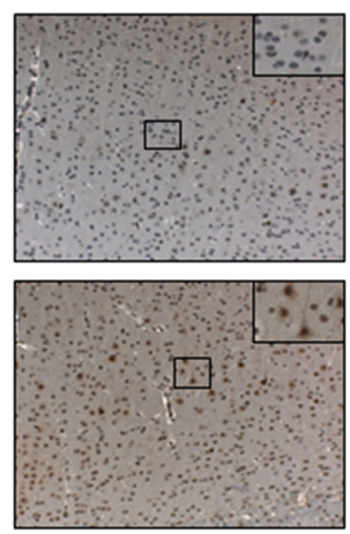

Cortex
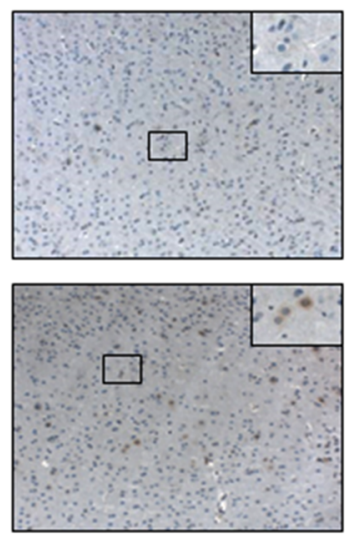

Cortex
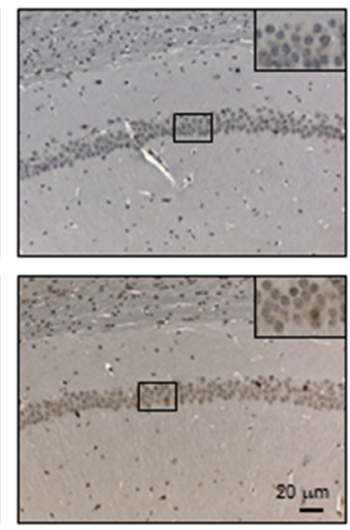

Hippocampus (CA1)
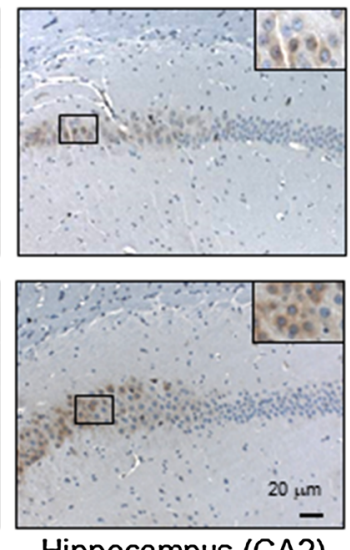

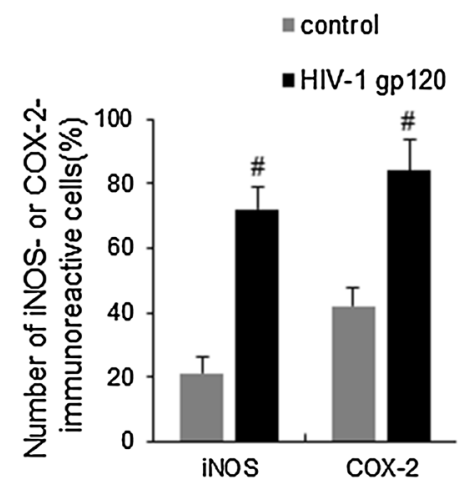

C

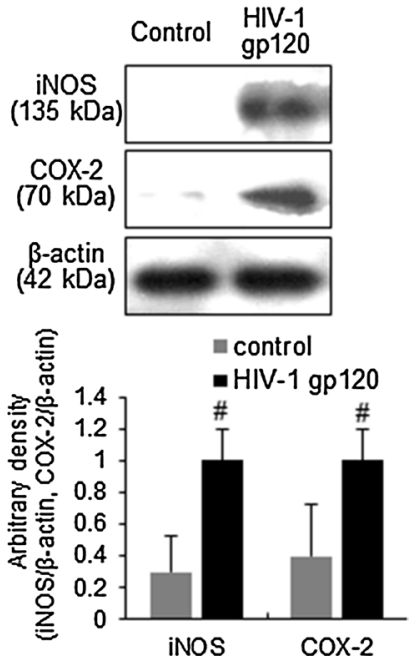

Fig. 5 Elevated effects of neuroinflammatory proteins on HIV-1 gp120-injected mice brain. Immunoreactive cells of iNOS (A) or COX-2 (B) antibody were detected in the cortex and hippocampus. $6 \mu \mathrm{m}$-thick sections of brains from mice were incubated with anti-iNOS or anti-COX-2 antibodies, and then the biotinylated secondary antibody. It was counterstained by hematoxylin. The resulting tissue was viewed with a microscope. The present figure is representative for three different experiments with different animal brains. C The expression of iNOS and COX-2 were detected by western blotting using specific antibodies. $\beta$-Actin protein was used here as an internal control. \#, Significantly different from control group $(p<0.05)$. Control, saline-injected group. HIV-1 gp120, HIV-1 gp120-injected group

IL-16, TIM-1, M-CSF, and ICAM-1 were elevated by HIV-1 gp120 protein in this study. Regarding these cytokines, there is a reported that association between polymorphisms in IL-16 and IL-2 genes and the risk of late-onset Alzheimer's disease (Anvar et al. 2015; Alves et al. 2016). M-CSF and ICAM were suggested as biomarkers for AD (Laske et al. 2010; Spangenberg et al. 2019). Thus, our animal study demonstrating induction of neuroinflammation by HIV-1 gp120 protein, as evidenced by the enhanced activation of microglial cells and astrocytes, increased COX-2 and iNOS expression, and the release of the several cytokines, supports the clinical findings regarding the correlation between HIV-1 infection and AD.

Activation of microglial and astrocyte cells and the onset of inflammatory reactions and related immunological responses also contribute to $A \beta$ accumulation. Recombinant gp120-injected primary hippocampal cells demonstrated the promotion of $\mathrm{A} \beta_{1-42}$ secretion (Aksenov et al. 2010). Increased expression of BACE1, an enzyme involved in the formation of $\mathrm{A} \beta$, was reported in $\mathrm{HIV}^{+}$ patients (Stern et al. 2018). It also was found that $A \beta$ is accumulated in HIV-1-infected individuals, even though the site of $A \beta$ deposition showed a discrepancy in the $A D$ brain (Achim et al. 2009; Andras and Toborek 2013). In the present study, we found that administration of the HIV-1 gp120 protein enhanced BACE expression, $\beta$-secretase activity, and $\mathrm{A} \beta$ accumulation, thus accelerating memory dysfunction (Lee et al. 2010). It is not yet clear how HIV-1 gp120 protein increases $A \beta$ production; however, it is noteworthy that HIV- 1 promotes $A \beta$ production through activated $\beta$ - and $\gamma$-secretase activities (Kim et al. 2013; Chai et al. 2017), and these effects may be associated with the modification of lipid rafts by extracellular vesicles by the virus (Mukhamedova et al. 2020). Several viruses, such 

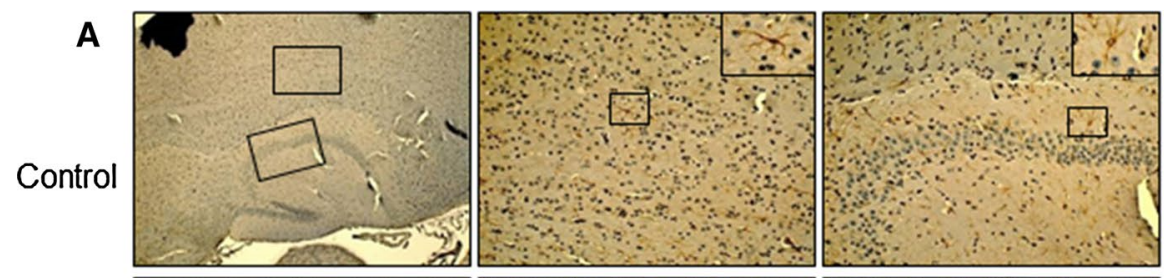

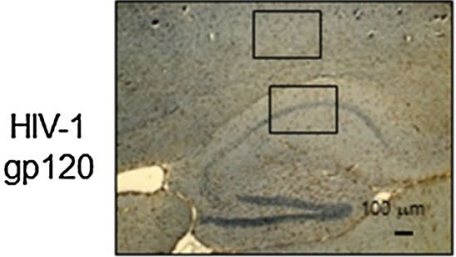

Whole

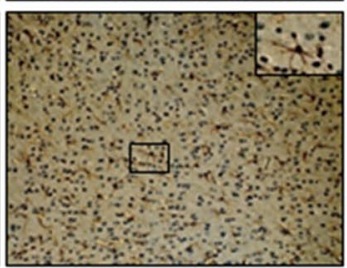

Cortex

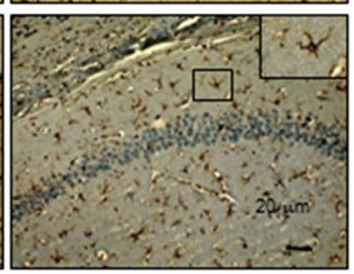

Hippocampus (CA1)

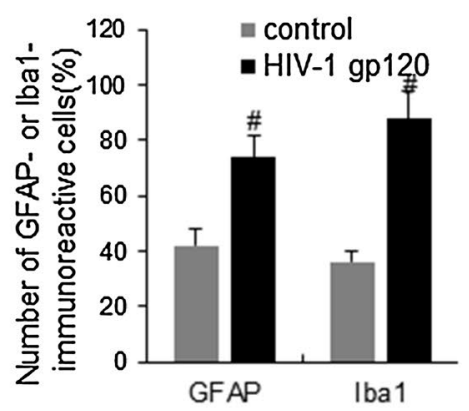

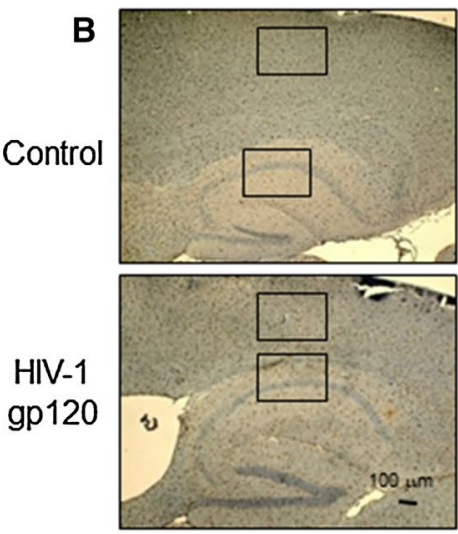

Whole
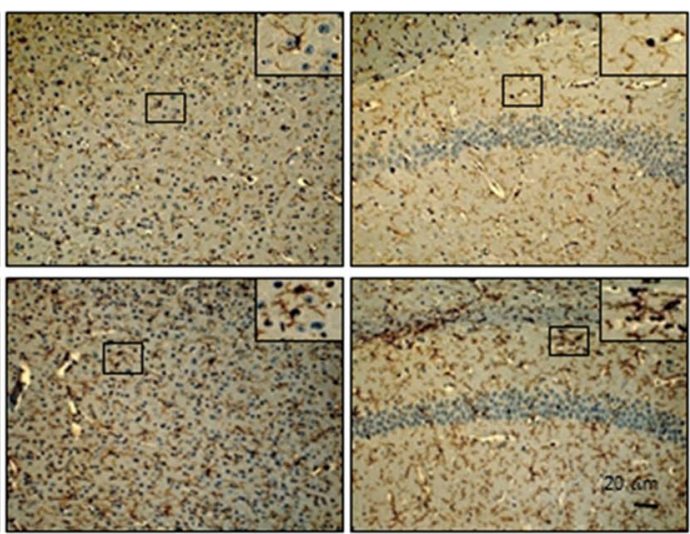

Cortex

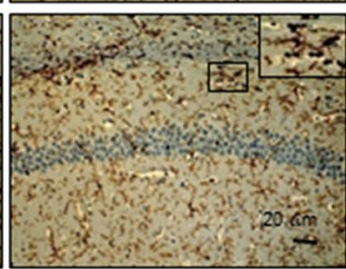

Hippocampus (CA1)

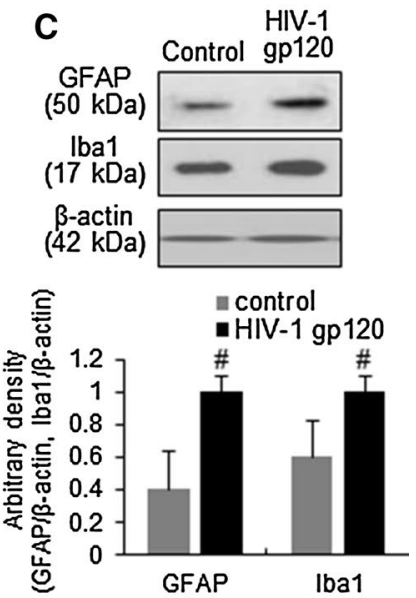

Fig. 6 Elevated effect of neuroinflammation on HIV-1 gp120-injected mice brain. A Immunoreactive cells of anti-GFAP antibody were investigated in the cortex and hippocampus. B Immunoreactive cells of anti-Ibal antibody were investigated in the cortex and hippocampus. The present figure is representative for three different experiments with different animal brains. C The level of GFAP and Iba1 was detected by western blotting using specific antibodies in mice brain. $\beta$-Actin protein was used as an internal control. \#, Significantly different from control group $(p<0.05)$. Control, saline-injected group. HIV-1 gp120, HIV-1 gp120-injected group

as cytomegalovirus, herpes simplex virus, HIV-1, severe acute respiratory syndrome (SARS) coronavirus, and SARS-CoV-2, have been found to be related to the cause of neurodegenerative diseases, such as $\mathrm{AD}$ (Lurain et al.
2013; Mawanda and Wallace 2013; Barnes et al. 2015; Ardura-Fabregat et al. 2017; Harris and Harris 2018; Lewczuk et al. 2018; Verkhratsky et al. 2019; Devanand et al. 2020; Hampel et al. 2020; Uddin et al. 2020), and clinical 
Fig. 7 Effect of neuroinflammation on HIV-1 gp120injected mice brain. A Cytokine profiles of saline- or gp120injected brain. B The level of IL-16, ICAM-1, M-CSF, TIM1, IL-2 and GAPDH expression as described in Materials and methods. Control, salineinjected group. HIV-1 gp120, HIV-1 gp120-injected group
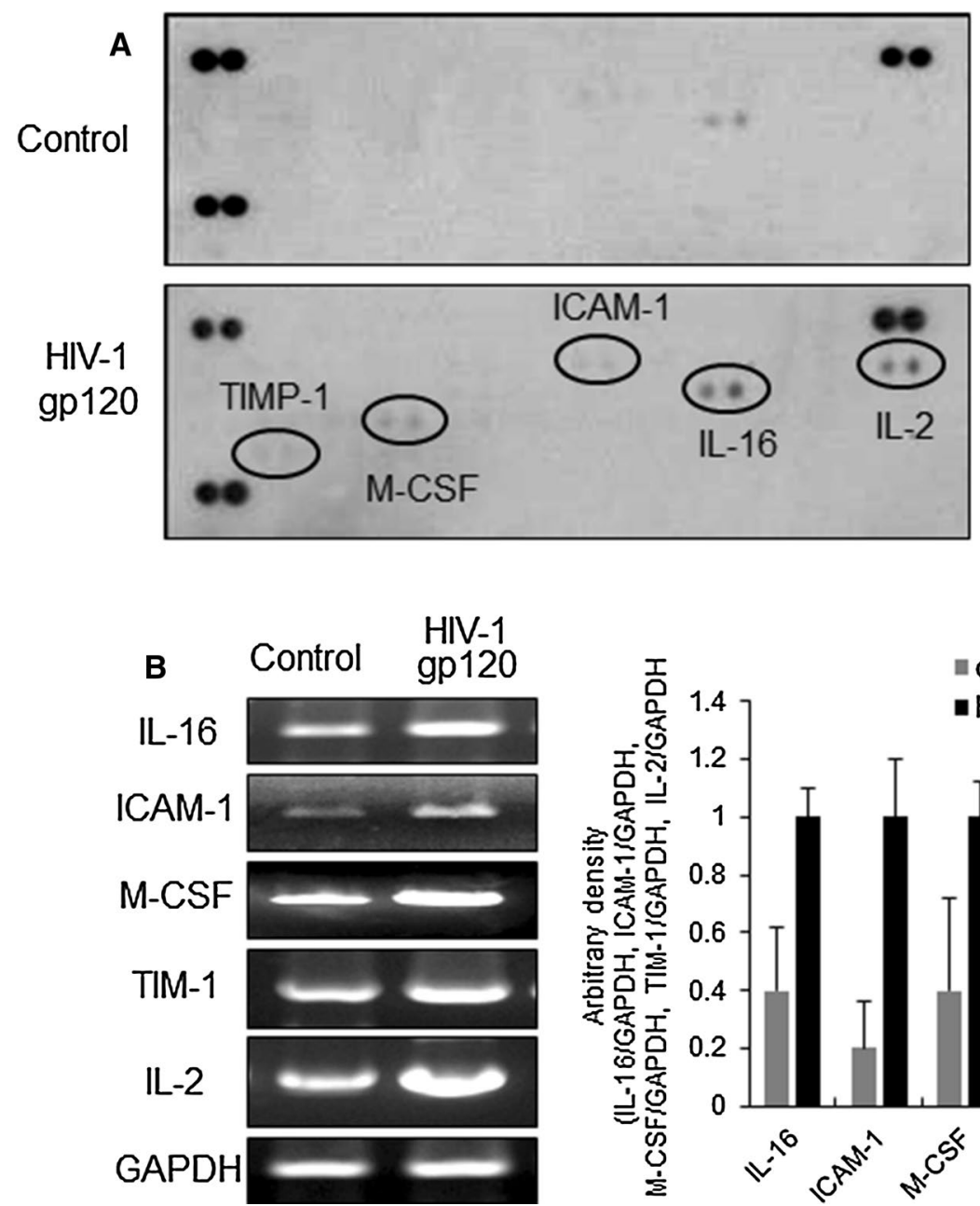

associations among viral infections and $\beta$-amyloid accumulation and neuroinflammation have also been observed. Therefore, the repurposing of anti-viral drugs as AD-treatment drugs could be possible. This present study demonstrated that viral infection could affect AD development and there may be an association between the amyloidogenic and neuroinflammatory properties of viruses.

Acknowledgements This work was supported by the National Research Foundation of Korea (NRF) grant funded by Korea government (MSIP) (No. MRC, 2017R1A5A2015541), and by Basic Science Research Program through the National Research Foundation of Korea (NRF) funded by the Ministry of Education (No. NRF-2018R1D1A3B07045440).

\section{Declarations}

Conflict of interest The authors declare that there are no conflicts of interest.

Open Access This article is licensed under a Creative Commons Attribution 4.0 International License, which permits use, sharing, adaptation, distribution and reproduction in any medium or format, as long as you give appropriate credit to the original author(s) and the source, provide a link to the Creative Commons licence, and indicate if changes were made. The images or other third party material in this article are included in the article's Creative Commons licence, unless indicated otherwise in a credit line to the material. If material is not included in the article's Creative Commons licence and your intended use is not permitted by statutory regulation or exceeds the permitted use, you will need to obtain permission directly from the copyright holder. To view a copy of this licence, visit http://creativecommons.org/licenses/by/4.0/.

\section{References}

Achim CL, Adame A, Dumaop W, Everall IP, Masliah E, Neurobehavioral Research C (2009) Increased accumulation of intraneuronal amyloid beta in HIV-infected patients. J Neuroimmune Pharmacol 4:190-199. https://doi.org/10.1007/s11481-009-9152-8

Aksenov M, Aksenova M, Mactutus C, Booze R (2010) HIV-1 protein-mediated amyloidogenesis in rat hippocampal cell cultures. Neurosci Lett 475:174-178. https://doi.org/10.1016/j.neulet.2010. 03.073

Alves S, Churlaud G, Audrain M, Michaelsen-Preusse K, Fol R, Souchet B, Braudeau J, Korte M, Klatzmann D, Cartier N (2016) Interleukin-2 improves amyloid pathology, synaptic failure and 
memory in Alzheimer's disease mice. Brain 140:826-842. https:// doi.org/10.1093/brain/aww330

Anderson E, Zink W, Xiong H, Gendelman HE (2002) HIV-1-associated dementia: a metabolic encephalopathy perpetrated by virus-infected and immune-competent mononuclear phagocytes. J Acquir Immune Defic Syndr 31:S43-S54. https://doi.org/10. 1097/00126334-200210012-00004

Andras IE, Toborek M (2013) Amyloid beta accumulation in HIV1 -infected brain: the role of the blood brain barrier. IUBMB Life 65:43-49. https://doi.org/10.1002/iub.1106

Anvar NE, Saliminejad K, Ohadi M, Kamali K, Daneshmand P, Khorshid HR (2015) Association between polymorphisms in Interleukin-16 gene and risk of late-onset Alzheimer's disease. J Neurol Sci 358:324-327. https://doi.org/10.1016/j.jns.2015.09.344

Ardura-Fabregat A, Boddeke E, Boza-Serrano A, Brioschi S, Castro-Gomez S, Ceyzeriat K, Dansokho C, Dierkes T, Gelders G, Heneka MT, Hoeijmakers L, Hoffmann A, Iaccarino L, Jahnert S, Kuhbandner K, Landreth G, Lonnemann N, Loschmann PA, Mcmanus RM, Paulus A, Reemst K, Sanchez-Caro JM, Tiberi A, Van Der Perren A, Vautheny A, Venegas C, Webers A, Weydt P, Wijasa TS, Xiang X, Yang Y (2017) Targeting neuroinflammation to treat Alzheimer's disease. CNS Drugs 31:1057-1082. https:// doi.org/10.1007/s40263-017-0483-3

Bachis A, Biggio F, Major EO, Mocchetti I (2009) M-and T-tropic HIVs promote apoptosis in rat neurons. J Neuroimmune Pharmacol 4:150-160. https://doi.org/10.1007/s11481-008-9141-3

Barnes LL, Capuano AW, Aiello AE, Turner AD, Yolken RH, Torrey EF, Bennett DA (2015) Cytomegalovirus infection and risk of Alzheimer disease in older black and white individuals. J Infect Dis 211:230-237. https://doi.org/10.1093/infdis/jiu437

Blennow K, De Leon MJ, Zetterberg H (2006) Alzheimer's disease. Lancet 368:387-403. https://doi.org/10.1016/S0140-6736(06) 69113-7

Chai Q, Jovasevic V, Malikov V, Sabo Y, Morham S, Walsh D, Naghavi MH (2017) HIV-1 counteracts an innate restriction by amyloid precursor protein resulting in neurodegeneration. Nat Commun 8:1522. https://doi.org/10.1038/s41467-017-01795-8

Choi DY, Lee YJ, Lee SY, Lee YM, Lee HH, Choi IS, Oh KW, Han SB, Nam SY, Hong JT (2012) Attenuation of scopolamineinduced cognitive dysfunction by obovatol. Arch Pharm Res 35:1279-1286. https://doi.org/10.1007/s12272-012-0719-1

Coughlin JM, Wang Y, Ma S, Yue C, Kim PK, Adams AV, Roosa HV, Gage KL, Stathis M, Rais R (2014) Regional brain distribution of translocator protein using [11 C] DPA-713 PET in individuals infected with HIV. J Neurovirol 20:219-232. https:// doi.org/10.1007/s13365-014-0239-5

Devanand DP, Andrews H, Kreisl WC, Razlighi Q, Gershon A, Stern Y, Mintz A, Wisniewski T, Acosta E, Pollina J, Katsikoumbas M, Bell KL, Pelton GH, Deliyannides D, Prasad KM, Huey ED (2020) Antiviral therapy: Valacyclovir Treatment of Alzheimer's Disease (VALAD) Trial: protocol for a randomised, double-blind, placebo-controlled, treatment trial. BMJ Open 10:e032112. https://doi.org/10.1136/bmjopen-2019-032112

Ferri CP, Sousa R, Albanese E, Ribeiro WS, Honyashiki M (2009) World Alzheimer Report 2009-executive summary. In: Prince M, Jackson J (eds) Alzheimer's disease international, London, pp 1-22. https://doi.org/10.18356/1d3bc170-en

Garden GA, Budd SL, Tsai E, Hanson L, Kaul M, D'emilia DM, Friedlander RM, Yuan J, Masliah E, Lipton SA (2002) Caspase cascades in human immunodeficiency virus-associated neurodegeneration. J Neurosci 22:4015-4024. https://doi.org/10.1523/ JNEUROSCI.22-10-04015.2002

Garvey LJ, Pavese N, Politis M, Ramlackhansingh A, Brooks DJ, Taylor-Robinson SD, Winston A (2014) Increased microglia activation in neurologically asymptomatic HIV-infected patients receiving effective ART. Aids 28:67-72. https://doi.org/10.1097/ 01.aids.0000432467.54003.f7

González-Scarano F, Martín-García J (2005) The neuropathogenesis of AIDS. Nat Rev Immunol 5:69-81. https://doi.org/10.1038/nri1527

Hampel H, Caraci F, Cuello AC, Caruso G, Nistico R, Corbo M, Baldacci F, Toschi N, Garaci F, Chiesa PA, Verdooner SR, AkmanAnderson L, Hernandez F, Avila J, Emanuele E, Valenzuela PL, Lucia A, Watling M, Imbimbo BP, Vergallo A, Lista S (2020) A path toward precision medicine for neuroinflammatory mechanisms in Alzheimer's disease. Front Immunol 11:456. https://doi. org/10.3389/fimmu.2020.00456

Harris SA, Harris EA (2018) Molecular mechanisms for herpes simplex virus type 1 pathogenesis in Alzheimer's disease. Front Aging Neurosci 10:48. https://doi.org/10.3389/fnagi.2018.00048

Hauser FK, Fitting S, Dever MS, Podhaizer ME, Knapp EP (2012) Opiate drug use and the pathophysiology of neuroAIDS. Curr HIV Res 10:435-452. https://doi.org/10.2174/157016212802138779

Kamat A, Lyons JL, Misra V, Uno H, Morgello S, Singer EJ, Gabuzda D (2012) Monocyte activation markers in cerebrospinal fluid associated with impaired neurocognitive testing in advanced HIV infection. J Acquir Immune Defic Syndr 60:234-243. https://doi. org/10.1097/QAI.0b013e318256f3bc

Kaul M, Garden GA, Lipton SA (2001) Pathways to neuronal injury and apoptosis in HIV-associated dementia. Nature 410:988-994. https://doi.org/10.1038/35073667

Kim J, Yoon JH, Kim YS (2013) HIV-1 Tat interacts with and regulates the localization and processing of amyloid precursor protein. PLoS ONE 8:e77972. https://doi.org/10.1371/journal.pone.00779 72

Laske C, Stransky E, Hoffmann N, Maetzler W, Straten G, Eschweiler GW, Leyhe T (2010) Macrophage colony-stimulating factor (M-CSF) in plasma and CSF of patients with mild cognitive impairment and Alzheimer's disease. Curr Alzheimer Res 7:409-414. https://doi.org/10.2174/156720510791383813

Lee YJ, Han SB, Nam SY, Oh KW, Hong JT (2010) Inflammation and Alzheimer's disease. Arch Pharm Res 33:1539-1556. https://doi. org/10.1016/s0197-4580(00)00124-X

Lewczuk P, Riederer P, O’bryant SE, Verbeek MM, Dubois B, Visser PJ, Jellinger KA, Engelborghs S, Ramirez A, Parnetti L, Jack CR Jr, Teunissen CE, Hampel H, Lleo A, Jessen F, Glodzik L, De Leon MJ, Fagan AM, Molinuevo JL, Jansen WJ, Winblad B, Shaw LM, Andreasson U, Otto M, Mollenhauer B, Wiltfang J, Turner MR, Zerr I, Handels R, Thompson AG, Johansson G, Ermann N, Trojanowski JQ, Karaca I, Wagner H, Oeckl P, Van Waalwijk Van Doorn L, Bjerke M, Kapogiannis D, Kuiperij HB, Farotti L, Li Y, Gordon BA, Epelbaum S, Vos SJB, Klijn CJM, Van Nostrand WE, Minguillon C, Schmitz M, Gallo C, Lopez Mato A, Thibaut F, Lista S, Alcolea D, Zetterberg H, Blennow K, Kornhuber J, Members of the Wfsbp Task Force Working on This Topic: Peter Riederer CGDKaLMFT (2018) Cerebrospinal fluid and blood biomarkers for neurodegenerative dementias: an update of the Consensus of the Task Force on Biological Markers in Psychiatry of the World Federation of Societies of Biological Psychiatry. World J Biol Psychiatry 19:244-328. https://doi.org/10.1080/15622975.2017.1375556

Lurain NS, Hanson BA, Martinson J, Leurgans SE, Landay AL, Bennett DA, Schneider JA (2013) Virological and immunological characteristics of human cytomegalovirus infection associated with Alzheimer disease. J Infect Dis 208:564-572. https://doi. org/10.1093/infdis/jit210

Mawanda F, Wallace R (2013) Can infections cause Alzheimer's disease? Epidemiol Rev 35:161-180. https://doi.org/10.1093/ epirev/mxs007

Minghetti L, Visentin S, Patrizio M, Franchini L, Ajmone-Cat MA, Levi G (2004) Multiple actions of the human immunodeficiency virus type-1 Tat protein on microglial cell functions. 
Neurochem Res 29:965-978. https://doi.org/10.1023/b:nere. 0000021241.90133 .89

Mollace V, Nottet HS, Clayette P, Turco MC, Muscoli C, Salvemini D, Perno CF (2001) Oxidative stress and neuroAIDS: triggers, modulators and novel antioxidants. Trends Neurosci 24:411416. https://doi.org/10.1016/S0166-2236(00)01819-1

Morris R (1984) Developments of a water-maze procedure for studying spatial learning in the rat. J Neurosci Methods 11:47-60. https://doi.org/10.1016/0165-0270(84)90007-4

Mukhamedova N, Huynh K, Low H, Meikle PJ, Sviridov D (2020) Isolation of lipid rafts from cultured mammalian cells and their lipidomics analysis. Bio Protoc 10:e3670. https://doi.org/10. 21769/BioProtoc. 3670

Ortega M, Ances BM (2014) Role of HIV in amyloid metabolism. J Neuroimmune Pharmacol 9:483-491. https://doi.org/10.1007/ s11481-014-9546-0

Peng H, Sun L, Jia B, Lan X, Zhu B, Wu Y, Zheng J (2011) HIV1 -infected and immune-activated macrophages induce astrocytic differentiation of human cortical neural progenitor cells via the STAT3 pathway. PLoS ONE 6:e19439. https://doi.org/10.1371/ journal.pone.0019439

Ru W, Tang S-J (2017) HIV-associated synaptic degeneration. Mol Brain 10:40. https://doi.org/10.1186/s13041-017-0321-z

Shadfar S, Hwang CJ, Lim MS, Choi DY, Hong JT (2015) Involvement of inflammation in Alzheimer's disease pathogenesis and therapeutic potential of anti-inflammatory agents. Arch Pharm Res 38:2106-2119. https://doi.org/10.1007/s12272-015-0648-x

Shah A, Verma AS, Patel KH, Noel R, Rivera-Amill V, Silverstein PS, Chaudhary S, Bhat HK, Stamatatos L, Singh DP (2011) HIV-1 gp120 induces expression of IL-6 through a nuclear factor-kappa B-dependent mechanism: suppression by gp120 specific small interfering RNA. PLoS ONE 6:e21261. https:// doi.org/10.1371/journal.pone.0021261

Spangenberg E, Severson PL, Hohsfield LA, Crapser J, Zhang J, Burton EA, Zhang Y, Spevak W, Lin J, Phan NY, Habets G, Rymar
A, Tsang G, Walters J, Nespi M, Singh P, Broome S, Ibrahim P, Zhang C, Bollag G, West BL, Green KN (2019) Sustained microglial depletion with CSF1R inhibitor impairs parenchymal plaque development in an Alzheimer's disease model. Nat Commun 10:3758. https://doi.org/10.1038/s41467-019-11674-z

Stern AL, Ghura S, Gannon PJ, Akay-Espinoza C, Phan JM, Yee AC, Vassar R, Gelman BB, Kolson DL, Jordan-Sciutto KL (2018) BACE1 mediates HIV-associated and excitotoxic neuronal damage through an APP-dependent mechanism. J Neurosci 38:4288-4300. https://doi.org/10.1523/JNEUROSCI.1280-17. 2018

Uddin MS, Kabir MT, Rahman MS, Behl T, Jeandet P, Ashraf GM, Najda A, Bin-Jumah MN, El-Seedi HR, Abdel-Daim MM (2020) Revisiting the amyloid cascade hypothesis: from antiabeta therapeutics to auspicious new ways for Alzheimer's disease. Int J Mol Sci 21:5858. https://doi.org/10.3390/ijms2 1165858

Verkhratsky A, Parpura V, Rodriguez-Arellano JJ, Zorec R (2019) Astroglia in Alzheimer's disease. Adv Exp Med Biol 1175:273324. https://doi.org/10.1007/978-981-13-9913-8_11

Zhang Y, Wang M, Li H, Zhang H, Shi Y, Wei F, Liu D, Liu K, Chen D (2012) Accumulation of nuclear and mitochondrial DNA damage in the frontal cortex cells of patients with HIV-associated neurocognitive disorders. Brain Res 1458:1-11. https://doi.org/ 10.1016/j.brainres.2012.04.001

Zhang Y, Ouyang Y, Liu L, Chen D (2015) Blood-brain barrier and neuro-AIDS. Eur Rev Med Pharmacol Sci 19:4927-4939. https:// www.europeanreview.org/wp/wp-content/uploads/4927-4939.pdf

Publisher's Note Springer Nature remains neutral with regard to jurisdictional claims in published maps and institutional affiliations. 